\title{
An intima affair adds to the dominion of the internal thoracic artery in coronary artery bypass grafting
}

\author{
Edward Buratto, MBBS, William Y. Shi, MBBS, and Igor E. Konstantinov, MD, PhD, FRACS
}

\footnotetext{
From the Department of Cardiothoracic Surgery, Royal Children's Hospital, Murdoch Children's Research Institute, University of Melbourne, Melbourne, Australia.

Disclosures: Authors have nothing to disclose with regard to commercial support.

Received for publication Feb 18, 2016; accepted for publication Feb 19, 2016; available ahead of print March 23 2016.

Address for reprints: Igor E. Konstantinov, MD, PhD, FRACS, Royal Children's Hospital, Flemington Rd, Parkville, VIC 3029, Australia (E-mail: igor.konstantinov@rch.org.au).

J Thorac Cardiovasc Surg 2016;151:1709-10

$0022-5223 / \$ 36.00$

Crown Copyright (c) 2016 Published by Elsevier Inc. on behalf of The American Association for Thoracic Surgery http://dx.doi.org/10.1016/j.jtcvs.2016.02.052
}

An important study on the histomorphologic differences between the internal thoracic artery (ITA) and the gastroepiploic artery (GEA) by Nakajima and colleagues ${ }^{1}$ is published in this issue of the Journal. By putting this study into perspective, it should be noted that it was initially observed in the very first studies ${ }^{2}$ that atherosclerosis could develop early in childhood, often after acute infection. The earliest signs of atherosclerosis and fatty streaks appear in the areas of sheer stress and increased intimal thickness. However, not all arteries are affected to the same degree. Of note, the ITA appears to be least affected. Historically, the ITA was the first graft to be used in coronary revascularization $^{3}$ and became the graft of choice because of its superior patency rate. A recent study from Melbourne provided strong evidence that the use of the right ITA as the second conduit provides a significant survival advantage. ${ }^{4}$ In this simple and convincing study, Nakajima and colleagues ${ }^{1}$ clearly demonstrated that there was no histomorphologic difference between left and right ITAs. Despite the evidence of the superiority of using bilateral ITAs, the technique remains underused, with bilateral ITAs used in only $4 \%$ of patients included in the Society of Thoracic Surgery database. ${ }^{5}$ The perceived and real drawbacks of bilateral ITA harvesting are the increased operative time and an increased risk of sternal wound infections, particularly in diabetic patients. ${ }^{4}$ It also became clear that the patency of the graft will depend on the target coronary artery. Any graft placed onto the left anterior descending coronary artery is expected to last longer than its equivalent grafted to the right coronary artery system. For these reasons, determination of the proper arterial graft for the right coronary artery system is of particular importance. ${ }^{6}$

The radial artery (RA) is a reliable conduit with good long-term patency. ${ }^{7}$ Because the RA is not always available, the GEA is an option. Suma and colleagues ${ }^{8}$ evaluated 625 patients who underwent GEA grafting and demonstrated long-term patency rates of $80.2 \%$ at 5 years and $62.5 \%$ at 10 years, substantially lower than what has been reported for ITA and RA grafts. not in the ITAs.

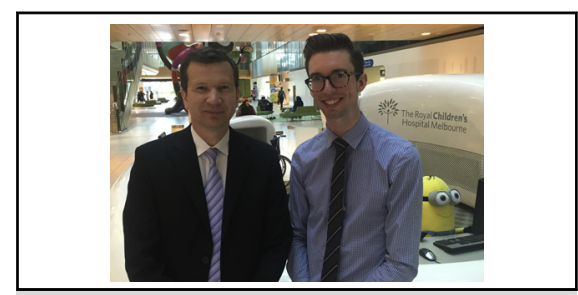

Igor E. Konstantinov, MD, PhD, FRACS, and Edward Buratto, MBBS

Central Message

The GEA has increased intimal thickness compared with bilateral ITAs, particularly in diabetic patients.

See Article page 1704.

In addition to its preferential use for the left anterior descending system, specific properties of the ITA may contribute to its superior patency. Greater release of nitric oxide and prostacyclin from the intima and betterdeveloped internal elastic lamina, which may protect the media from noxious stimuli and prevent the migration of muscle cells into the intima, are thought to protect the ITA from atherosclerotic processes. It is fascinating that not all species of warm-blooded animals even have an intima. In humans, the intima develops only after birth and forms completely by 6 months of age.' As humans progress into adulthood, intimal hyperplasia could be a forerunner of developing atherosclerotic plaques.

Intuitively, it can be presumed that increased intimal thickness would make the arterial graft more prone to atherosclerosis. However, there is no evidence in the literature to confirm or refute the opinion that intimal thickness is related to arterial graft failure. Most important, Nakajima and colleagues ${ }^{1}$ demonstrated correlation of intimal thickness with diabetes in GEA, but not in either ITA. GEAs from patients with poorly controlled diabetes had increased intimal thickness. Furthermore, atherosclerotic plaques were observed in the GEAs, but

The study of Nakajima and colleagues ${ }^{1}$ adds further biological evidence to the clinical finding that the ITA is the best conduit, particularly in diabetic patients. However, a practical challenge is to apply bilateral ITA grafting in diabetic patients without increased risk of sternal wound complication. The skeletonization approach to the ITA harvesting may decrease the risk of sternal wound infection. ${ }^{10}$ 
Bilateral ITA grafting with complete revascularization maximizes long-term survival and is recommended for patients with diabetes. ${ }^{10}$

In conjunction with the extensive and increasing clinical evidence of the superiority of bilateral ITAs over other conduits, this study provides further important evidence to encourage the use of bilateral ITAs more often.

\section{References}

1. Nakajima T, Tachibana K, Takagi N, Ito $T$, Kawaharada N. Histomorphological superiority of internal thoracic arteries over right gastroepiploic arteries for coronary bypass. J Thorac Cardiovasc Surg. 2016;151: 1704-8.

2. Konstantinov IE, Mejevoi N, Anichkov NM, Nikolai N. Anichkov and his theory of atherosclerosis. Tex Heart Inst J. 2006;33:417-23.

3. Konstantinov IE. Vasilii I. Kolesov: a surgeon to remember. Tex Heart Inst J. 2004;31:349-58.

4. Shi WY, Hayward PA, Tatoulis J, Rosalion A, Newcomb AE, Fuller JA, et al. Are all forms of total arterial revascularization equal? A comparison of single versus bilateral internal thoracic artery grafting strategies. J Thorac Cardiovasc Surg. 2015;150:1526-34.
5. Tabata M, Grab JD, Khalpey Z, Edwards FH, O'Brien SM, Cohn LH, et al. Prevalence and variability of internal mammary artery graft use in contemporary multivessel coronary artery bypass graft surgery: analysis of the Society of Thoracic Surgeons National Cardiac Database. Circulation. 2009; 120:935-40.

6. Glineur D, D'hoore W, de Kerchove L, Noirhomme P, Price J, Hanet C, et al. Angiographic predictors of 3-year patency of bypass grafts implanted on the right coronary artery system: a prospective randomized comparison of gastroepiploic artery, saphenous vein, and right internal thoracic artery grafts. J Thorac Cardiovasc Surg. 2011; 142:980-8.

7. Buxton BF, Shi WY, Tatoulis J, Fuller JA, Rosalion A, Hayward PA. Total arterial revascularization with internal thoracic and radial artery grafts in triple-vessel coronary artery disease is associated with improved survival. J Thorac Cardiovasc Surg. 2014;148:1238-43.

8. Suma H, Isomura T, Horii $T$, Sato $T$. Late angiographic result of using the right gastroepiploic artery as a graft. J Thorac Cardiovasc Surg. 2000;120: 496-8.

9. Schwartz SM, deBlois D, O'Brian ER. The intima. Soil for atherosclerosis and restenosis. Circ Res. 1995; 77:445-65.

10. Raza S, Sabik JF, Masabni K, Ainkaran P, Lytle BW, Blackstone EH. Surgical revascularization techniques that minimize surgical risk and maximize late survival after coronary artery bypass grafting in patients with diabetes mellitus. J Thorac Cardiovasc Surg. 2014;148:1257-64. 